\title{
Empirical Study on Pricing Formation Mechanism of Transfer of Rural Land Contractual Management Rights
}

\author{
Ma Hui ${ }^{1 *}$, Zhang Yanqiu ${ }^{2}$ \\ ${ }^{1}$ College of Arts and Law of Wuhan University of Technology, Wuhan Hubei, China \\ ${ }^{2}$ College of Arts and Law of Wuhan University of Technology, Wuhan Hubei, China \\ *email:15977440@qq.com
}

\begin{abstract}
The core of issues concerning "agriculture, countryside and farmers" is rural land problems. The transfer of rural land contractual management rights should be premised on scientific and normative pricing formation mechanism. Adopted the empirical and investigation study method, based on field research in Xinzhou District in Wuhan, Hubei Province, this paper analyzes the current situation of pricing formation mechanism of transfer of rural land contractual management rights, and concludes factors with influence on transfer price of rural land contractual management rights. The conclusion is drawn that transfer price of rural land contractual management rights is mainly affected by three factors: the national policy, the village custom and the current situationof market. The paper strives to establish a scientific and reasonable circulating price formation mechanism of rural land contracted management rights, in order to promote the rural land in our country circles healthy and smoothly and protect the farmers' interest as well.
\end{abstract}

Key Words:rural land contractual management rights, transfer price, pricing formation mechanism, Fenghuang Town

\section{Introduction}

The right to land contractual management is a property right in nature, a kind of usufruct derived from agricultural land. On the premise that the land remains to be used for agriculture, its transfer price should be the natural quality price of the land, depending on the future economic value of the agricultural land as well as profits from agricultural land management, degree of risk for agricultural business and years of transfer. ${ }^{[1]}$ That is to say, price of land contractual management rightsshould consist of social price, economic price and ecological price(as its shown in the table 1.).

Social price of land contractual management rights is the market value of the social benefits of land contract management rights, among which the most important is existence value of land contracting management, that is, the sum of its values of employment and survival guarantee for farmers and its price of social stability due to its role of providing society with food security.

Economic price of land contractual management rights, also known as quality price, is the market value of productivity, i.e. transaction of agricultural products from lands in the market.

According to the theory of land externality, agricultural lands, as a special type of 
land use, will have more or less influence on the whole landscape ecosystem. And ecological price of land contractual management rights is its monetized value of this kind.

Table 1.The price structure of land contractual management rights

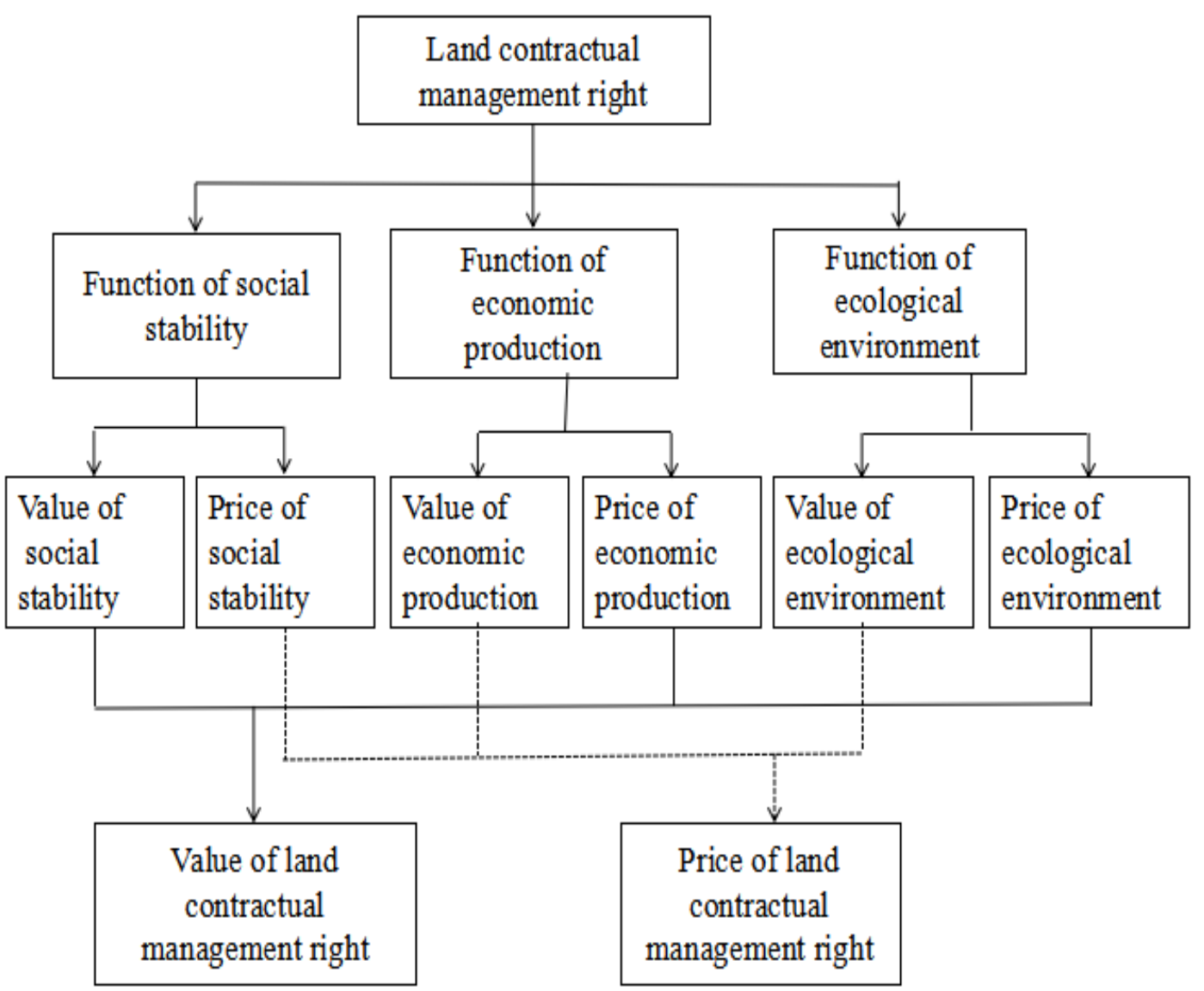

\section{Features of pricing formation mechanism of transfer of rural land contractual management right in China}

In order to have more understanding of pricing formation mechanism of transfer of rural land contractual management right in China, a special research was made in Fenghuang Town, Xinzhou District, Wuhan, Hubei Province and relevant research results are as shown below(Figure 1.). Thereinto: 355,000mu lands are transferred, accounting for $49 \%$ of cultivated lands.

Figure 1. Land structure in Xinzhou District in ten thousand mu

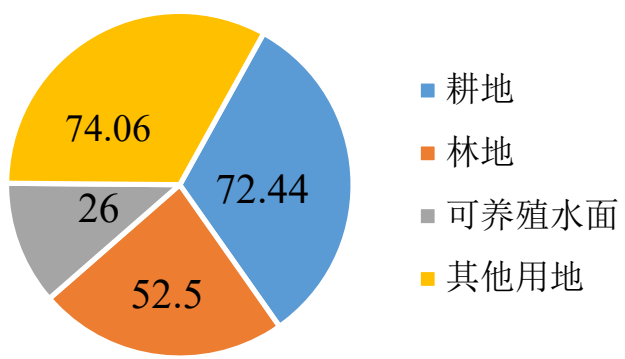

In general, with the special research in Xinzhou District, pricing formation 
mechanism of transfer of rural land contractual management rights has the following characteristics:

\subsection{The transfer of land contractual management rights is priced at will}

In the current transfer of rural land contractual management rights, the transfer price is generally made by a collective economic organization and individual farmers or other operating entities in consultation with each other. The transfer market develops differently. In areas with well developed transfer market, the price is set spontaneously in the market according to the supply and demand, but in areas with a little transactions or less developed market, the price can be made at will ${ }^{[2]}$. Since transfer price of land contractual management rights among villages and/or towns in same area or neighboring areas differs, so as the transfer price of rural land contractual management rights in same period and transfer price of contractual management rights to rural lands with the same function, transfer price of rural land contractual management rights has no regularity in most areas.

\subsection{Farmers are not enthusiastic about land transfer}

It can be concluded from research results that most farmers are reluctant to transfer the right to rural land contracting management for the following two basic reasons: First, under present conditions, the right to rural land contracting management and the agricultural lands involved are "weak properties" unable to demonstrate property value and utility for farmers, thus farmers have a fewer expectations to get the property interests and values contained in this "weak properties" through transfer or by other means, and hence few farmers desire to "make big money" through transfer of rural land contractual management rights. Second, with current urban-rural dual structure and rural economy development level, the right to rural land contracting management and the agricultural lands involved are "power guarantee" for the most basic survival right for farmers ${ }^{[3]}$. Currently, China's social security system in rural areas is not perfect, so farmers worry that they would lose basic living guarantee after transfer of lands. This conflict between "weak properties" and "powerful guarantee" significantly prevents farmers from transferring lands.

\subsection{As ways of transfer differ, price differs}

According to integration and statistics of research data, there are following ways of transfer in Fenghuang Town as shownbelow(Figure 2.). It can be seen from the figure that lands in Fenghuang Town are mainly transferred through subcontracting and leasing. Subcontracting usually occurs among farmers in a rural collective organization and lands transferred by subcontracting are of small area and scattered distribution at lower price; and price of lands transferred in verbal agreement is rather lower. Leasing is usually made by a village committee to attract investment; and the village committee, as an intermediary, organizes farmers to rent the contracted lands to private persons or enterprises in foreign areas for scale planting; the contracted lands are of large area and are concentrated and contiguous with higher transfer price. 
Figure 2. Ways of land transfer in Fenghuang Town and their proportions

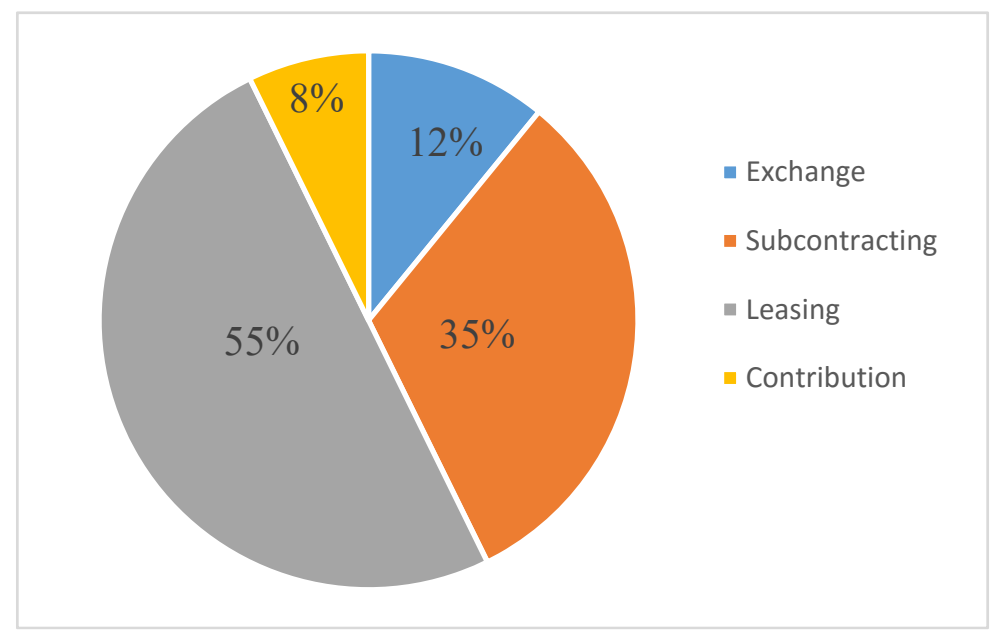

\section{Analysis of factors influencing transfer price of rural land contractual management rights in China}

There are many factors with influence on transfer price of rural land contractual management rights. However, it is found from research that there are mainly three factors with impact on market-oriented transfer price of rural land contractual management rights, namely:

\subsection{National policy and transfer price}

The transfer price of rural land contractual management rights in China is affected by perfection of the social security system in China. The transfer price of land contractual management rights cannot be determined by rules of market economy completely. Thus, multi-social functions of rural lands must be considered. And this is the main reason for low transfer price of rural land contractual management rights in various areas in China at present, especially in rural areas where the non-agricultural industry is underdeveloped.

\subsection{Village custom and transfer price}

The majority of farmers in China, especially in the relatively closed rural areas, have stronger traditional ideas. Generally, village customers will make the transfer prices greatly different from each other. From the perspective of subjects in land transfer, transfer price between common farmers is higher than that of between relatives and neighbors, so kindred and neighborhoods relationship, kinship and marriage relationship can lower transaction cost and price of agricultural lands in land transfer. ${ }^{[4]}$ The reason behind is influence of village customs mainly. Villagers would feel embarrassed to put up the transfer price for sake of their close relationship, thus curbing the transfer price. It is thus clear that "acquaintance society" can lower transfer price of agricultural lands.

\subsection{Current situation of market and transfer price}

Perfect market system and competitive market state are the basic factors influencing market price formation. In view of the present situation of transfer of land contractual management rights in China, it is mainly because the market competition is not sufficient or the market development is not balanced or there is no competition 
that the transfer price is generally deviated from its value, either at "abnormally high price" or "abnormally low price", reflecting no actual price accurately. Therefore,

\section{Conclusion}

Land is the important natural resource that mankind relies on for survival and development and the core problem related to countryside, agriculture and farmers. Therefore, the land problem is the main breakthrough to solve problems concerning "agriculture, countryside and farmers". It's crucial for deepening rural reform to further improve and innovate land system, to protect rights and interests of farmers' land properties, to provide the most basic institutional guarantee for stable growth of farmers' income and to create conditions enabling more farmers to get income from property based on realistic demands of increasing farmers' income and narrowing the gap between urban and rural areas. A scientific and reasonable pricing formation mechanism of transfer of rural land contractual management rights is of great theoretical and practical significance to improve and perfect transfer market of rural land contractual management rights, to promote smooth transfer of it, to achieve scale management of lands and to protect limited land resources.

\section{References}

[1]Zhou Jianchun:Study on Theory and Techniques of Cultivated Land Valuation. China Land Publising,Beijing(2006),p.142.

[2]Xiong Ying:Effects of Land Use Change on the Ecosystem Service Function in Red Soil Hilly Region-a Case Study Of Changsha City.Journal of Hunan University (Natural Sciences)(2009).

[3]Li Junbo: The Reality of Rural Land Contract Operation Rights Transfer, Analysis and Legal Thinking.Hebei Law Science(2009).

[4]Deng Dacai: Institutional Arrangement, Transaction Cost and Transfer Price of Agricultural Lands.Academic Journal of Zhongzhou(2009).

[5] Chang Huanhuan,Yu Yun,Guo Yongsheng,Chen Xiaodi: Development Model and Characteristics of Rural Land Joint Stock-cooperative System.Asian Agricultural Research(2012).

[6]Chen Hanbing: Research on the Circulation Problems of Contractual Management Right of Rural Land. Asian Agricultural Research(2010).

[7]DingChengri: The benchmark land price system and urban land use efficiency in China[J]. Chinese Geographcal Science(2011).

[8]Shuai Xiaolin: The construction strategy of China's rural land transfer price mechanism. Journal of social science(2012).

[9]Mu Songlin: Research on the transfer price of regional land contract management right.Henan University,Kaifeng(2010).

[10] Lu Jie,Jiang Hui,Wu Kening: Discussion on the price of land contract management rights transfer-a case study of Henan province. Anhui Social Sciences(2010). 